\section{WALLACE ON THE ORIGIN OF INSECTS*}

$A$ MID all the discussions to which the question of the Origin $\mathrm{A}^{\mathrm{M}}$ of Insects has given rise, it is to me surprising that one of the most ingenious and remarkable theories ever put forth on a question of natural history has not been so much as once alluded to. More than six years ago, Mr. Herbert Spencer published, in his "Principles of Biology," a view of the nature and origin of the annulose type of animals, which goes to the very root of the whole question; and, if this view is a sound one, it must so materially affect the interpretation of all embryological and anatomical facts bearing on this great subject, that those who work in ignorance of it can hardly hope to arrive at true results. $\mathrm{I}$ propose, therefore, to lay before you a brief sketch of $\mathrm{Mr}$. Spencer's theory, with the hope of calling attention to it, and inducing some of you to take up what seems to me to be a most promising line of research; and, although the question is one on which I feel quite incompetent to form a sound judgment, I shall call your attention to the light which it seems to throw on some of the most curious anomalies of insect structure.

The theory itself may be enunciated in very few words. It is, that insects, as well as all the Annulosa, are not primarily single individuals, but that each one is a compound, representing as many individuals as there are true segments in the body, these individuals having become severally differentiated and specialised to perform certain definite functions for the good of the whole compound animal.

Mr. Spencer first calls attention to the fact, that among the undoubtedly compound animals (which are almost all found in the sub-kingdoms, Colenterata and Molluscoida) the several individuals are rarely combined in such a nanner as to necessitate any physiological division of labour amoug them. The associated individuals of aHydrozoon or an Ascidian are each free to spread their tentacles, to draw in currents of water, and to select their food, without in any way interfering with each other, because the compound animal is either branched or approximately hemispherical, and thus there is no necessity for any of the combined inaividuals to become especially modified with regard to the rest. But should a compound animal have its component individuals arranged in a linear series, there would most probably arise a marked difference of conditions between the two situated at the extrenities and those between them. If they remained united, some modification must have occurred to adapt each to its condition. But if, further, the series should be fixed at one end, the other being free, a new differentiation must arise; for the two ends being very differently situated, the intermediate ones will also differ accordingly as they are nearer one end or the other. Here there is a cause for the differentiation of united individuals that does not exist in any branched or other symmetrical arrangement than a linear one. Some of the Salpidæ show such a zudimentary linear aggregation, but their mouths and vents being lateral the individuals are so similarly situated that no differentiation need occur. A little consideration will show us that this is one of those cases in which perfectly transitional forms are not to be expected. A permanent union of individuals in a linear series, such as to necessitate differentiation of function among them, could only be effected by a series of co-ordinated grada. tions, each of which would have so great an advantage over its predecessor as to necessitate its extinction in the struggle for existence. We cannot expect to find the union without the differentiation, or the differentiation without the complete union; and it will, therefore, be impossible to prove that such was the origin of any group of animals, except by showing that numerous traces of separate individualities occur in their organisation, and cannot be explained by any of the known laws of development or growth in animals not so compounded.

In the structure of the lower Annelids we do find strong indications of such an ancestral fusion of distinct individuals. These animals are composed of segments, not merely superficial, but exhibiting throughout a wonderful identity of form and structure. Each segment has its branchiæ, its enlargement of the alimentary canal, its contractile dilatation of the great blood-vessel, its ganglia, its branches from the nervous and vascular trunks, its organs of reproluction, its locomotive appendages, and, sometimes, even its pair of eyes. Thus every segment is a physiological whole, having all the organs essential to life and multiplication. Again, just as other compound animals increase by gemmation or fission, so do these. The embryo leaves the

* Extracted from an Address read at the Anniversary Meeting of the Ento. * Extracted from an Adress read at the Anniversary Meeting of the Ento-
mological Society of London on the 2and January, 1872 , by Alfred R.
Wallace, F.L.S., F.Z.S., President, \&c. egg a globular ciliated gemmule ; elongation and segmentation then take place, always in the hinder part, so as to elongate the compound animal without interfering with the more specialised anterior segment. In the Nemertidæ, and some Planaria, spontaneous fission occurs, each part becoming a perfect animal, and in the Tænia this is the usual mode of reproduction. The account given by Professor Owen in his "Comparative Anatomy of Invertebrates" is very suggestive of Mr. Spencer's view. He says :- "On the first appearance of the embryo annelid it usually consists of a single segment, which is chiefly occupied by a large mass of unmetamorphosed germ-cells. And these are not used up, as in higher animals, in developing the tissues and organs of an undivided or individual whole, but, after a comparatively slight growth and change of the primary segment, proceed in the typical orders to form a second segment of somewhat simpler structure, and then repeat such formations in a linear series, perhaps more than a hundred times. So that we may have a seeming individual annelid, consisting of many hundred segments, in which a single segment would give all the characteristic organisation of such individual, except some slight additions or modifications, characterising the first and last of the series." $\mathrm{He}$ also tells us that spontaneous fission has now been observed to take place in almost every order of Annulata ; and, in many, artificial fission produces two distinct individuals. In some cases the compound animal consists of very few segments, three only in the genus Chætogaster, the fourth always separating as a zooid, and forming a new animal. In the higher Articulata, the process of gemmation goes on to a considerable extent in the egg, and even afterwards in some cases, but more or less irregularly. Thus the larva of Iulus is hatched with eight segments, and at the first moult it acquires six new ones, which are added between the last and the penultimate.

The gradual fusion of the once distinct individuals into a complete unity, is shown in a very interesting manner as we advance from the lower to the higher forms. In the Annelida, Dr. Carpenter tells us, the spiracles of each segment are separate, and do not communicate internally with those of other segments. In the Myriapoda they partially communicate, while in the Insecta they communicate perfectly by a system of anastomosing vessels. The same thing is indicated by the various positions of the chief spiracles. In Smynthurus among the Poduridx there are only two, opening under the side of the head immediately beneath the antennæ. In Solpugidæ (Arachnida) they are situated between the anterior feet; in some spiders they open near the end of the abdomen, in others at its base. The position of the mouth and eyes at the anterior extremity of the body, and the vent at the posterior, are obviously what would arise as soon as any specialisation of function in the series of zooids occurred. It is not, therefore, surprising that we never find these change their position. But for the respiratory and generative organs there is no such necessity for fixity of position, and as they existed originally in every segment, we can well conceive how, as articulate forms become more and more modified, it would sometimes be useful to the compound animal for these organs to become abortive or developed in different parts of the body. We have seen that this is to some extent the case with the former organs, but it occurs to a much greater extent with the latter.

The most generalised form is to be seen in the intestinal worms, each segment of which possesses a complete hermaphrodite reproductive apparatus ; so that, in this respect, no less than in their capacity for spontaneous fission, these creatures are really what we should expect the early type of compound animals to be. This, however, is a rare case, but even in the much higher leeches there are testes in no less than nine of the segments, and Dr. Williams discovered a direct passage from the spermatheca to the ovaries, which seems to indicate internal self-fertilisation. It is, however, in the lower Arthropoda that we find the most curious diversities in the position of these organs. In the Glomeridæ the genital openings in both sexes are situated in the third segment, just behind the insertion of the second pair of limbs. In the Polydesmidæ the female organs are in the third segment, while those of the male are in the seventh segment. In Iulus the same organs are situated in the fourth and seventh segments respectively. The Chilopoda, on the other hand, have them near the end of the body, as in most insects. In the Acarina the ovaries open on the middle of the abdumen or on the under side of the thorax, either between or behind the last pair of legs. In spiders the seminal orifice is at the base of the abdomen, but the palpi are the intromittent 
organs; these are spoon-shaped, and are besides armed with horny processes, hooks, and other appendages, and must be looked upon as true generative organs. In the Astacida the sexual organs of the male are at the base of the first pair of abdominal legs, those of the female at the base of the third pair. Among the true winged-insects there is one remarkable case of abnormal position of these organs, in the dragon flies, which have the seminal vessels in the ninth, while the complex male sexual organs are situated in the second, abdominal segment. It is interesting to note that this curious anomaly occurs in an order which is considerea to be of the greatest antiquity and most generalised type among the true insects.

There are many other facts of a similar character to those I have now touched upon, and they all become clearly intelligible on the theory of Mr. Spencer, that the Annulosa are really compound animals, or, as he expresses it, "aggregates of the third order " while the other great groups of highly organised animals-Mollusca and Vertebrata-are typically simple animals, or "aggregates of the second order," (the cells of which their structures are built up being "aggregates of the first order"). Nothing of a similar character is to be found among the two latter groups. No molluscous or vertebrate animal can be divided transversely so that the separate segments shall be in any degree alike, and contain repetitions of any important organs. The distinct separation of parts in the vertebral column has been acquired, for it is less visible in the lower types than in the higher (the reverse of what obtains among insects), and in the lowest of ali is quite absent; while in none is there any corresponding multiplicity or displacement of respiratory, circulatory, or generative organs. The vertebral column corresponds rather to the segmenied shell of the Chiton, and has no more relation than it to the essential plan of the more important vital organs. Neither does any mollusk or vertebrate undergo spontaneous fission, nor that complete and progressive segmentation in the process of development which is characteristic of all Arnulosa ; nor do they ever exhibit the phenomena of parthenogenesis or alternation of generations, the essential feature of both which is, that numerous individuals are produced from a single fertilised ovum, by a process analogous to (or perhaps identical with) ordinary gemmation, and both which phenomena sometimes occur even among the higher insects.

In concluding this short sketch of a remarkable theory, I would observe, that if it is a true one it at once invests the objects of our study with a new and exceptional interest; because they are the most highly developed portion of a group of animals which will, in that case, differ fundamentally in their plan of structure from all other highly organised forms of life. In the study of the habits, instincts, and whole economy of insects, we shall have to keep ever in view the conception of a number of individualities fused into one, yet perhaps retaining some separateness of mental action, a conception which may throw light on many an obscure problem, and which will perhaps materially influence our ideas as to the nature of life itself. We must remember also, that if the insect is really a compound animal, then the only true homology that can exist between it and a vertebrate, or a mollusk, will be one between a single segment and an entire animal, and the search after any other will be so much lost time. Especially must the acceptance of this theory have an important bearing on all embryological and genetical studies ; and if the facts and arguments adduced by its learned and philosophical author do make out even a prima facie case in its favour, it must deserve the careful and unbiassed consideration of all who endeavour to solve the problem of the Origin of Insects.

\section{THE AUSTRALIAN ECLIPSE EXPEDITION}

$W E$ have already announced that no scientific results are to be expected from the Australian Eclipse Expedition, owing to the unpropitious state of the weather. The following particulars are obtained from the Melbourne Arous:-

"The five days intervening between the arrival at No. VI. Island and the eclipse were employed by the astronomical party in erecting and testing the instruments. Tents had to be put up, brick foundations and pedestals built, and distances determined. There was plenty of hard work, and the time at the disposal of the astronomers was found to be none too much. Nor were those who had to sleep on shore with the instruments to be envied. Possession of the island was hotly disputed by legions of rats, who behaved in the most impudent manner They boldly eyed the operations in the daytime, winking wickedly from behind the tufts of grass. Every night they held a corroboree in the tents, coursing over the instruments and the forms of the wearied sleepers, gnawing hats and any baggage which promised a toothsome morsel ; and in some instances they had the audacity to bite the men who attempted to brush them away. The passengers filled up the interval by visits to the mainland, and one or two of the neighbouring reefs and islets. On Thursday, December 8, Mr. Moore formed a party and went to Cape Sidmouth, the boat carrying provisions for three or four days. A native on the beach seemed much alarmed at their approach. When they landed he ran off at full speed and was not seen again. Only two other blackfellows showed themselves, though the tracks and camp fires proved that there were many in the neighbourhood. These blacks were known to be hostile, and it was necessary to take precautions to guard against a surprise. The master of the schooner Challenge, from Sydney, bound for Cape York, passed with his vessel a few yards astern of the Governor Blackall that morning. On hearing that a party had set out with the intention of landing at Cape Sidmouth, he expressed the consoling opinion that if they entered the bush they would never come out of it again. But no such disaster befel.

"On the hills, which rose abruptly a few hundred yards from the beach, were well-defined quartz reefs, and the neighbourhood presented all the appearance of auriferous country. A few miles from Cape Sidmouth was found an enormous heap of the bones of the dugong, the strange mammal which inhabits these seas. There were nearly two tons of bones, piled up in fantastic array, with all the skulls on top. At every turn were ant-hills, rising in solid cones from $6 \mathrm{ft}$. to $12 \mathrm{ft}$. high, and almost as hard as granite. Some of them had fine pinnacles, and these airy minarets, clustered together in graceful shapes, had a very pleasing effect. The numerous screw pines were also an agreeable feature in the landscape. The mountains, eight or ten miles inland, were well wooded, with occasional abrupt squares of grassed land.

"Mr. Moore prosecuted his botanical researches on the main. land during two days. Those who understand botany may be interested to learn from his account that the high ground at the cape is sparsely covered with stunted growths and trees, chiefly Eucaiypti and Grevillea chrysantha. Advancing into the interior, broad-leaved acacias and arborescent species of Hakea and Melaleuca principally characterise the open forest country. There are belts of thick jungle scrub of no great width, in which a very slender and graceful palm, which is believed to be new, occurs in great abundance. A species of Nepenthes, or pitcher plant, is also found in great profusion. Araliaceous trees are numerous. Ferns are scarce, but in the open forest the ground is thickly covered with Schizaa dichotoma. A very remarkable plant was found as an undergrowth in this, having large white bracts and bright green foliage. It is supposed to be a species of Mussanda. Toward the north of the cape is a long, low, flat country, chiefly covered with mangrove. The sandy patches contain a variety of undershrubs and climbers, with a tree here and there. The silk-cotton plant (Cochlospermum gossypium) also varies the scene with its delicate flower. Among these shrubs a very interesing plant-a species of Eugenia-was found. It bears a fruit about the size and colour of a cherry, having a pleasant sub-acid flavour. This fruit was largely eaten by the party, and the tree which bears it is supposed to be well worthy of cultivation. The vegetation is otherwise principally characterised by a species of Busbeckia, Elcodendron, Hibiscus, Bauhinia, and a species of Banksia. After leaving the mainland the party visited No. VII. Island of the Claremont group, where Mr. Brazier added an Auricula and a Bulimus to his previous collection of shells, which included specimens of the genera Diplommatina, Pupa, Halicarion, Helzx, Truncatella, Pythia, and Cassidula. Had the expedition selected a portion of the mainland for the observing point, there would have been some interesting and extensive explorations in the interior. The party were fully equipped with arms and ammunition, some supplied by the Government and some privately owned, but with the ship nine miles off, and the limited time at our disposal, much exploration was impracticable. In any case, there was no anchorage for the vessel within two miles of the shore, and that was one of the reasons why the island was preferred for the observatory.

"On Thursday afternoon, some of the excursionists went in the captain's boat to look for shells on a small sandbank which had come into view, and landed on an island considerably smaller 